\title{
Nuclear Factor of Activated T Cells Operates as Conductor of the Epigenetic Orchestra in Pancreatic Carcinogenesis
}

\author{
Elisabeth Hessmann Volker Ellenrieder \\ Signaling and Transcription Laboratory, Department of Gastroenterology, \\ Philipps University, Marburg, Germany
}

\section{Key Words}

Nuclear factor of activated T cells · Pancreatic carcinogenesis · Gene activation and silencing

\begin{abstract}
Recent years have witnessed an explosive increase in our knowledge about the epigenetic features in human cancers. It became apparent that pancreatic cancer, additionally to its genetic background, is an epigenetic disease characterized by widespread alterations in DNA methylation, histone modification and recruitment of microRNAs. Although more and more in-depth research is performed and epigenetic modifications are shown in healthy and degenerated cells, we still lack insight into how epigenetic modifications are orchestrated during carcinogenesis. By introducing nuclear factor of activated T cell proteins and their impact on gene activation and silencing in pancreatic cancer, this review cites an example of how deregulated oncogenes modulate epigenetic alterations in epithelial cancers.
\end{abstract}

(C) 2013 S. Karger AG, Basel

\section{Introduction}

Within the last decade, epigenetic modifications shifted into the center of attention in the field of developmental and medical research. Once it became clear that DNA is not deleted from somatic cells after the completion of development, the question remained how somatic cells express different phenotypes although they retain the same DNA [1]. Due to its stability and strong conservation, additional features linked to the DNA sequence must exist that are more dynamic and can account for the alterations between the genotype and the phenotype of a cell. 
Hessmann et al.: Nuclear Factor of Activated T Cells Operates as Conductor of the Epigenetic Orchestra in Pancreatic Carcinogenesis

The mechanisms linking the stability of the DNA sequence with the wide range of cellular phenotypes are summed up under the term of 'epigenetics'. Epigenetics is defined as any heritable genomic mechanism unrelated to changes in the DNA sequence [2]. There are several well-known epigenetic mechanisms subdivided into DNA methylation, histone modification and microRNAs, all of them affecting the cell by induction or suppression of gene expression [3-7]. For instance, posttranslational modification of histone tail residues highly influences the structure and activity of chromatin. While acetylation of histones is primarily associated with transcriptional activation, methylation of histones can lead to both, activation and repression, depending on the modified residue [8, 9]. Epigenetic modifications are applicable to normal cellular development and maintenance, but they are also responsible for the deregulation of gene expression, resulting in diseased cellular phenotypes. Most notably, the deregulation of epigenetic mechanisms can contribute to cancer development [10-16].

One of the most aggressive malignancies is ductal adenocarcinoma of the pancreas (PDAC) [17]. Due to the late diagnosis in advanced stages, early invasion and metastases as well as extreme resistance to conventional therapy, pancreatic cancer has a 5-year mortality rate of 97-98\% [18]. As a result of its dismal prognosis, many concerns were expressed in the last few decades over understanding the background of pancreatic cancer biology. In 2008, Jones et al. [19] discovered 1,561 somatic gene mutations within more than 20,000 analyzed genes, yielding an average rate of 63 genetic abnormalities per pancreatic cancer, clustered in 12 regulatory pathways. Conceptually, these data suggest that pancreatic cancer is substantially a disease of pathways. However, research into these pathways made it clear that these cascades must ultimately take on the function of epigenetic regulators to silence tumor suppressors and activate oncogenes in a heritable manner. Thus, studies into epigenetics in pancreatic cancer are a logical extension to the genetic paradigm of this malignant disease.

Many excellent reviews exist about epigenetic mechanisms active in pancreatic cancer $[1,2,20-22]$ but less is known about the pathways and transcription factors orchestrating histone modifications, DNA methylation and recruitment of microRNAs. Based on the oncogenic transcription factor NFAT (nuclear factor of activated $\mathrm{T}$ cell) and its implication in histone modifications in pancreatic cancer, this review will focus on transcription factors that initiate epigenetic changes and influence the assembly of chromatin on key genes responsible for pancreatic cancer development.

\section{NFAT Transcription Factors in Pancreatic Carcinogenesis and Established Pancreatic Cancer}

Pancreatic cancer evolves through a series of histopathological changes, referred to as acinar-to-ductal metaplasia and progressive pancreatic intraepithelial neoplasia, which are accompanied by a recurrent pattern of genetic and epigenetic alterations, the earliest and most prevalent of which is oncogenic activation of Kras. Constitutive activation of Kras $\left(\right.$ Kras $\left.^{\mathrm{G} 12 \mathrm{D}}\right)$ is generally accepted to represent the initial key event in pancreatic carcinogenesis and found in virtually all invasively growing pancreatic tumors [23].

The relevance of Kras ${ }^{\mathrm{G} 12 \mathrm{D}}$ mutation to pancreatic carcinogenesis has been elegantly demonstrated in genetically engineered mouse models with conditional activation of this oncogene [24]. These studies revealed that constitutive activation of Kras alone is not sufficient for neoplastic progression; instead additional abnormalities and signals from the inflammatory environment are necessary to promote pancreatic cancer [25]. This type of proinflammatory environment can be provided by chronic pancreatitis, the most relevant risk factor for PDAC development in human beings [26]. Chronic pancreatitis supports the initi- 
Hessmann et al.: Nuclear Factor of Activated T Cells Operates as Conductor of the Epigenetic Orchestra in Pancreatic Carcinogenesis

ation and progression of this malignancy by direct modification of gene expression networks in pancreatic epithelial cells, predominantly of inflammatory transcription factors.

One of these inflammatory transcription factors is the NFAT family (isoforms NFATc1c5), originally identified as a group of inducible nuclear proteins, which regulate the transcription during T lymphocyte activation [27]. However, a multitude of studies quickly established that NFAT proteins are also expressed in other cell systems than the immune system, where they participate in the regulation of the expression of genes influencing cell growth and differentiation. Ectopic activation of NFAT members is now recognized as an important aspect of oncogenic transformation in several human malignancies, most notably in pancreatic cancer [28].

Upon calcium-dependent activation of calcineurin, the phosphatase targets and dephosphorylates NFAT, which leads to its nuclear translocation. In the nucleus, NFAT proteins form nucleoprotein complexes with other transcription factors and DNA-binding proteins for subsequent target gene regulation [29].

In pancreatic cancer, NFAT proteins take on highly oncogenic qualities downregulating tumor suppressor genes and promoting oncogenes. A significant amount of NFAT-dependent oncogenic processes with implications in pancreatic carcinogenesis and established pancreatic cancer comprise or result in epigenetic alterations, predominantly histone modifications. For this purpose, NFAT transcription factors cooperate with chromatin-remodeling proteins to induce the activation or silencing of target genes.

\section{NFATc1 and p300 Cooperate for c-Myc Activation in Pancreatic Cancer}

As an immediate early transcription factor, proto-oncogenic c-Myc functions as a master regulator of G1-S cell cycle progression and growth promotion in pancreatic cancer [29, 30]. In pancreatic cancer cells, serum-induced c-Myc expression and cancer growth are mediated by fast and sustained stimulation of the $\mathrm{Ca}^{2+}$ /calcineurin/NFAT signaling and transcription pathway. Mechanistically, NFATc1 binding to the serum-responsive element within the proximal c-Myc promoter initiates p300-dependent histone acetylation rendering the promoter transcriptionally active. Hyperacetylation of the c-Myc promoter is required for recruitment of ELK1, a protein signaling downstream of Kras, responsible for maximal activation of c-Myc. The functional significance of this pathway is emphasized by impaired c-Myc expression, reduced tumor growth and G1 arrest following the pharmacological or genetic inactivation of NFATc1 (fig. 1a) [30].

\section{NFAT and STAT3 Cooperation Regulates Key Genes in Pancreatic Carcinogenesis via Enhancer-Promoter Communications}

Recent investigations by our group established that NFATc1 cooperates with the inflammatory transcription factor STAT3 to promote Kras ${ }^{\mathrm{G} 12 \mathrm{D}}$-driven carcinogenesis. NFATc1 activation accelerates pancreatitis-mediated carcinogenesis in Kras ${ }^{\mathrm{G} 12 \mathrm{D}}$ mice, whereas its genetic or pharmacological inactivation attenuates this effect. From the mechanistic point of view, NFATc1 interacts with STAT3 to form enhancer-promoter communications at jointly regulated genes involved in inflammation and oncogenesis, e.g. EGFR and Wnt family members. The NFATc1-STAT3 transcription pathway is operative in pancreatitis-mediated carcinogenesis as well as in established human pancreatic cancer (fig. 1b) [Baumgart et al., in press]. 
Hessmann et al.: Nuclear Factor of Activated T Cells Operates as Conductor of the

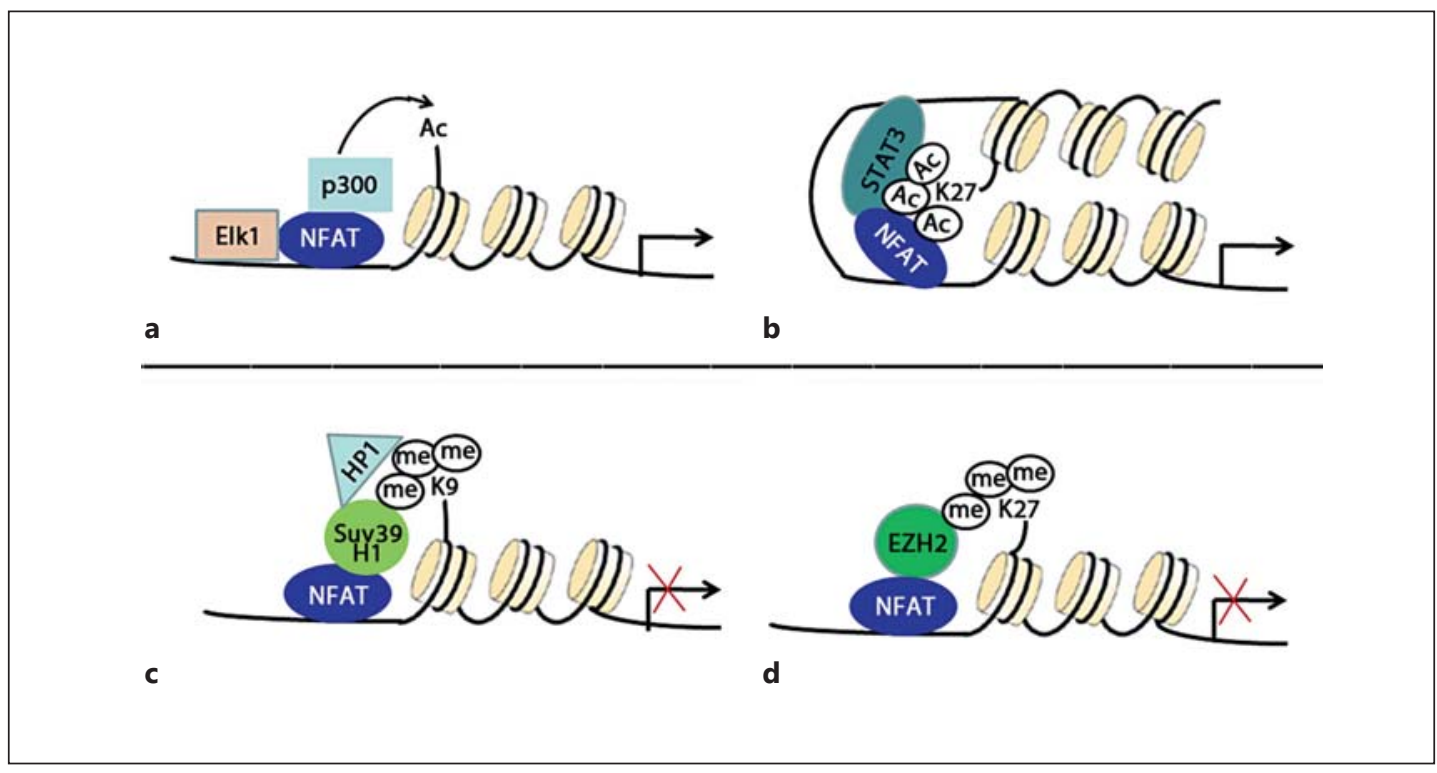

Fig. 1. a NFAT proteins interact with histone acetyltransferase p300 for histone 3 acetylation inducing a chromatin structure allowing Elk1 binding to the c-Myc promoter. b NFAT cooperates with STAT3 via enhancer-promoter communications to activate target genes. c NFAT binding to target genes leads to the formation of local heterochromatin by sequential recruitment of the histone methyltransferase Suv39H1 and HP1 proteins. d NFAT acts in concert with the Polycomb group member EZH2 to silence target genes.

\section{NFAT Recruits the Histone Methyltransferase Suv39H1 for Silencing the Tumor Suppressor p15}

Activation of NFAT proteins does not only lead to target gene activation in pancreatic cancer, but also contributes to gene silencing. Being a member of the Ink4 family, p15 Ink4b impedes the activation and function of cyclin-dependent kinases 4 and 6, which leads to cell cycle inhibition and diminished G1-S phase transition [31]. Therefore, $\mathrm{p} 15^{\text {Ink4b }}$ incorporates important functions such as being a tumor suppressor in numerous malignancies, most importantly in pancreatic cancer. $\mathrm{p} 15^{\text {Ink } 4 \mathrm{~b}}$ inactivation by genetic or epigenetic events occurs in over $90 \%$ of all tumors [19]. NFATc2 targets $\mathrm{p} 15^{\text {Ink4b }}$ for inducible and sequential heterochromatin formation and gene silencing. Sequential chromatin immunoprecipitation revealed that NFATc2 binding to its putative binding side on the $\mathrm{p} 15^{\mathrm{Ink} 4 \mathrm{~b}}$ promoter leads to recruitment of the histone methyltransferase Suv39H1. Local trimethylation of lysine 9 on histone 3 (H3K9trime) allows docking of heterochromatin protein $1 \gamma$, which results in the stabilization of the heterochromatin complex on the $\mathrm{p} 15^{\operatorname{Ink} 4 \mathrm{~b}}$ promoter. Conflicting with that, the inactivation of NFATc2 disrupts the repressor complex and results in the restoration of p15 $5^{\text {Ink } 4 \mathrm{~b}}$ expression and function (fig. 1c) [32].

\section{NFAT Participates in the Polycomb Group Protein Function by Cooperating with EZH2 in Established Pancreatic Cancer}

The term 'Polycomb' was first coined almost 80 years ago to describe additional sex comb formation in Drosophila melanogaster resulting from a loss of homeotic (Hox) gene expression [33]. Polycomb protein complexes induce gene repression via H3K27 trimethylation [34]. 
Hessmann et al.: Nuclear Factor of Activated T Cells Operates as Conductor of the Epigenetic Orchestra in Pancreatic Carcinogenesis

Polycomb proteins can be divided into two functional biochemical categories: Polycomb repressive complexes (PRC) 1 and 2. While members of the PRC2 complex initiate gene repression by the catalyzation of $\mathrm{H} 3 \mathrm{~K} 27$ trimethylation, proteins belonging to PRC1 maintain the repressive state $[35,36]$. Under physiological conditions, the activity of Polycomb proteins is crucial in the development as well as in the maintenance and proliferation of pluripotent progenitor cells in a variety of tissues. Overexpression of these proteins may promote tumorigenesis by fostering a self-renewing population of cells [37, 38]. Indeed, overexpression of Polycomb proteins is responsible for malignant progression and poor prognosis in breast [39], bladder [40] and prostate [41] cancer, and shows a strong association with hallmarks of cancer, including induced cellular proliferation [42], angiogenesis [43], survival [44] and migration [45].

EZH2 is the only PRC2 protein member thus far studied in pancreatic cancer. Strong nuclear accumulation of EZH2 was found in 55\% of well-differentiated tumors and in $98 \%$ of poorly differentiated samples in a comprehensive immunohistochemical analysis of PDAC, indicating a significant correlation between EZH2 expression and dedifferentiation in pancreatic cancer [46]. Additionally, EZH2 overexpression participates in epithelial mesenchymal transition and invasion through the repression of epithelial proteins like E-cadherin [47].

As the core PRC1 and PRC2 proteins lack any DNA binding capabilities, the question remains, how Polycomb complexes modify the chromatin of target genes. Recent evidence from our group investigating pancreatic cancer cells clearly shows that NFAT induces EZH2 on the transcriptional level and partners with methyltransferase to control the expression of target genes involved in pancreatic cancer (fig. 1d) [unpubl. data].

\section{Perspective}

These examples of NFAT-mediated epigenetic changes in pancreatic cancer only demonstrate a small insight into how oncogenic transcription factors contribute to pancreatic cancer development by orchestrating chromatin-remodeling programs.

In addition to the striking number of genetic changes, epigenetic alterations constitute another layer of complexity and contribute to the heterogeneity of pancreatic cancer. The era of epigenetics in pancreatic cancer has emerged strongly within the last few years and deepened our understanding of pancreatic cancer biology. One of the most important characteristics of epigenetic mechanisms, which clearly demarcate them from genetics, is their reversibility. This feature provides new targets for novel therapeutic interventions in pancreatic cancer and other epithelial tumors.

However, the challenge still remains to distinguish between physiological epigenetic mechanisms operative in every single cell and the deregulation of histone modification, DNA methylation and recruitment of microRNAs, contributing to cancer development, especially when it comes to targeting epigenetic alterations in new therapeutic cancer approaches. Therefore, the careful analysis of cancer-specific deregulated programs with an impact on the induction of epigenetic changes might open new doors in cancer cell-specific therapy.

\section{Acknowledgements}

This work was generously supported by the Deutsche Forschungsgemeinschaft (to V.E.: KFO210, SFB-TR17) and the German Cancer Research Foundation (to V.E.: No. 109423 'Inflammation and Cancer' and AK 'Mildred Scheel' Fellowship). 
Hessmann et al.: Nuclear Factor of Activated T Cells Operates as Conductor of the Epigenetic Orchestra in Pancreatic Carcinogenesis

\section{References}

1 McCleary-Wheeler AL, Lomberk GA, Weiss FU, Schneider G, Fabbri M, Poshusta TL, Dusetti NJ, Baumgart S, Iovanna JL, Ellenrieder V, Urrutia R, Fernandez-Zapico ME: Insights into the epigenetic mechanisms controlling pancreatic carcinogenesis. Cancer Lett 2013;328:212-221.

-2 Omura N, Goggins M: Epigenetics and epigenetic alterations in pancreatic cancer. Int J Clin Exp Pathol 2009; 2:310-326.

3 Lopez-Serra L, Esteller M: Proteins that bind methylated DNA and human cancer: reading the wrong words. Br J Cancer 2008;12:1881-1885.

4 Zagni C, Chiacchio U, Rescifina A: Histone methyltransferase inhibitors: novel epigenetic agents for cancer treatment. Curr Med Chem 2013;20:167-185.

5 Lorincz AT: The promise and the problem of epigenetics biomarkers in cancer. Expert Opin Med Diagn 2011; 5:375-379.

6 Lujambio A, Calin GA, Villanueva A, Ropero S, Sanchez-Cespedes M, Blanco D, Montuenga LM, Rossis S, Nicoloso MS, Faller WJ, Gallagher WM, Eccles SA, Croce CM, Esteller M: A microRNA DNA methylation signature for human cancer metastasis. Proc Natl Acad Sci USA 2008;105:13556-13561.

7 Berger SL: Histone modifications in transcriptional regulation. Curr Opin Genet Dev 2002;12:142-148.

$>8$ Jenuwein T, Allis CD: Translating the histone code. Science 2001;293:1074-1080.

-9 Lachner M, Jenuwein T: The many faces of histone lysine methylation. Curr Opin Cell Biol 2002;14:286-298.

10 Esteller M: Epigenetic gene silencing in cancer: the DNA hypermethylome. Hum Mol Genet 2007;16:R50-R59.

11 Eden A, Gaudet F, Waghmare A, Jaenisch R: Chromosomal instability and tumors promoted by DNA hypomethylation. Science 2003;300:455.

12 Tufarelli C, Stanley JA, Garrick D, Sharpe JA, Ayyub H, Wood WG, Higgs DR: Transcription of antisense RNA leading to gene silencing and methylation as a novel cause of human genetic disease. Nat Genet 2003;34:157165.

13 Fabbri M, Garzon R, Cimmuno A, Liu Z, Zanesi N, Callegari E, Liu S, Adler H, Costinean S, Fernandez-Cymering C, Volinia S, Guler G, Morrison CD, Chan KK, Marcucci G, Calin GA, Huebner K, Croce CM: MicroRNA-29 family reverts aberrant methylation in lung cancer by targeting DNA methyltransferases $3 \mathrm{~A}$ and 3B. Proc Natl Acad Sci USA 2007; 104:15805-15810.

14 Yamada N, Nishida Y, Tsutsumida H, Hamada T, Goto M, Higashi M, Nomoto M, Yonezawa S: Muc1 expression is regulated by DNA methylation and histone H3 lysine 9 modification in cancer cells. Cancer Res 2008;68: 2708-2716.

15 Vincent A, Ducourouble MP, van Seuningen I: Epigenetic regulation of the human mucin gene Muc4 in epithelial cancer cell lines involves both DNA methylation and histone modifications mediated by DNA methyltransferases and histone deacetylases. FASEB J 2008;22:3035-3045.

16 Sparmann A, van Lohuizen M: Polycomb silencers control cell fate, development and cancer. Nat Rev Cancer 2006;6:846-856.

17 Hidalgo M: Pancreatic cancer. N Engl J Med 2010;362:1605-1617.

18 Singh M, Maitra A: Precursor lesions of pancreatic cancer: molecular pathology and clinical applications. Pancreatology 2007;7:9-19.

19 Jones S, Zhang X, Parsons DW, Lin JC, Leary RJ, Angenendt P, Mankoo P, Carter H, Kamiyama H, Jimeno A, Hong SM, Fu B, Lin MT, Calhoun ES, Kamiyama M, Walter K, Nikolskaya T, Nikolsky Y, Hartigan J, Smith DR, Hidalgo M, Leach SD, Klein AP, Jaffee EM, Goggins M, Maitra A, Iacobuzio-Donahue C, Eshleman JR, Kern SE, Hruban RH, Karchin R, Papadopoulos N, Parmigiani G, Vogelstein B, Velculescu VE, Kinzler KW: Core signaling pathways in human pancreatic cancer revealed by global genomic analyses. Science 2008;321:1801-1806.

20 Singh S, Ellenrieder V: Senescence in pancreatic carcinogenesis: from signalling to chromatin remodelling and epigenetics. Gut 2013;62:1364-1372.

21 Sato N, Goggins M: The role of epigenetic alterations in pancreatic cancer. J Hepatobiliary Pancreat Surg 2006; $13: 382-395$

22 Ottenhof NA, Wilde RF, Maitra A, Hruban RH, Offerhaus GJA: Molecular characteristics of pancreatic ductal adenocarcinoma. Patholog Res Int 2011;2011:620601.

23 Hruban RH, Maitra A, Goggins M: Update on pancreatic intraepithelial neoplasia. Int J Clin Exp Pathol 2007;1: 306-316.

-24 Hingorani SR, Wang L, Mutani AS, Combs C, Deramaudt TB, Hruban RH, Rustgi AK, Chang S, Tuveson DA: Trp53R172H and KrasG12D cooperate to pomote chromosomal instability and widely metastic pancreatic ductal adenocarcinoma in mice. Cancer Cell 2005;7:469-483.

25 Pylayeva-Gupta Y, Lee KE, Hajdu CH, Miller G, Bar-Sagi D: Oncogenic Kras-induced GM-CSF production promotes the development of pancreatic neoplasia. Cancer Cell 2012;21:836-847.

26 Yadav D, Lowenfels AB: The epidemiology of pancreatitis and pancreatic cancer. Gastroenterology 2013;144: 1252-1261.

27 Diehl S, Chow CW, Weiss L, Palmetshofer A, Twardzik T, Rounds L, Serfling E, Davis RJ, Anguita J, Rincon M: Induction of NFATc2 expression by interleukin 6 promotes T helper type 2 differentiation. J Exp Med 2002; 196:39-49.

28 Buchholz M, Ellenrieder V: An emerging role for $\mathrm{Ca}^{2+} /$ calcineurin/NFAT signaling in cancerogenesis. Cell Cycle 2007;6:16-19. 
Hessmann et al.: Nuclear Factor of Activated T Cells Operates as Conductor of the Epigenetic Orchestra in Pancreatic Carcinogenesis

29 Buchholz M, Schatz A, Wagner M, Michl P, Linhart T, Adler G, Gress TM, Ellenrieder V: Overexpression of c-myc in pancreatic cancer caused by ectopic activation of NFATc1 and the $\mathrm{Ca}^{2+} /$ calcineurin signaling pathway. EMBO J 2006;25:3714-3724.

-30 König A, Linhart T, Schlengelmann K, Reutlinger K, Wegele J, Adler G, Singh G, Hofmann L, Kunsch S, Büch T, Schäfer E, Gress TM, Fernandez-Zapico ME, Ellenrieder V: NFAT-induced histone acetylation relay Switch promotes c-Myc-dependent growth in pancreatic cancer cells. Gastroenterology 2010;138:1189-1199.

31 Gil J, Peters G: Regulation of the IN4b-ARF-INK4a tumour suppressor locus: all for one and one for all. Nat Rev Mol Cell Biol 2006; 7:667-677.

-32 Baumgart S, Glesel E, Singh G, Chen NM, Reutlinger K, Zhang J, Billadeau DD, Fernandez-Zapico ME, Gress TM, Singh SK, Ellenrieder V: Restricted heterochromatin formation links NFATc2 repressor activity with growth promotion in pancreatic cancer. Gastroenterology 2012;142:388-398.

-33 Grzenda A, Ordog T, Urrutia R: Polycomb and the emerging epigenetics of pancreatic cancer. J Gastrointest Cancer 2011;42:100-111.

-34 Cao R, Wang L, Wang H, Xia L, Erdjument-Bromage H, Tempst P, Jones RS, Zhang Y: Role of histone H3 lysine 27 methylation in Polycomb-group silencing. Science 2002;298:1039-1043.

-35 Czermin B, Melfi R, McCabe D, Seitz V, Imhof A, Pirrotta V: Drosophila enhancer of Zeste/ESC complexes have a histone H3 methyltransferase activity that marks chromosomal Polycomb sites. Cell 2002;111:185-196.

-36 Shao Z, Raible F, Mollaaghababa R, Guyon JR, Wu CT, Bender W, Kingston RE: Stabilization of chromatin structure by PRC1, a Polycomb complex. Cell 1999;98:37-46.

37 Lee TI, Jenner RG, Boyer LA, Guenther MG, Levine SS, Kumar RM, Chevalier B, Johnstone SE, Cole MF, Isono K, Koseki H, Fuchikami T, Abe K, Murray HL, Zucker JP, Yuan B, Bell GW, Herbolsheimer E, Hannett NM, Sun K, Odom DT, Otte AP, Volkert TL, Bartel DP, Melton DA, Gifford DK, Jaenisch R, Young RA: Control of developmental regulators by Polycomb in human embryonic stem cells. Cell 2006;125:301-313.

38 Molovsky AV, Pardal R, Iwashita T, Park IK, Clarke MF, Morrison SF: Bmi-1 dependence distinguishes neural stem cell self-renewal from progenitor proliferation. Nature 2003;425:962-967.

-39 Saeki M, Kobayashi D, Tsuji N, Kuribayashi K, Watanabe N: Diagnostic importance of overexpression of Bmi-1 mRNA in early breast cancers. Int J Oncol 2009;35:511-515.

40 Qin ZK, Yang JA, Ye YL, Zhang X, Xu LH, Zhou FJ, Han H, Liu ZW, Song LB, Zeng MS: Expression of BMI-1 is a prognostic marker in bladder cancer. BMC Cancer 2009;9:61.

-41 Xu K, Wu ZJ, Groner AC, He HH, Cai C, Lis RT, WU X, Stack EC, Loda M, Liu T, Xu H, Cato L, Thornton JE, Gregory RI, Morrissey C, Vessella RL, Montironi R, Magi-Galluzzi C, Kantoff PW, Balk SP, Liu XS, Brown M: EZH2 oncogenic activity in castration-resistant prostate cancer cells is Polycomb-independent. Science 2012;338:14651469.

42 Tonini T, Bagella L, D’Andrilli G, Claudio PP, Giodano A: Ezh2 reduces the ability of HDAC1-dependent pRb2/ p130 transcriptional repression of cyclin A. Oncogene 2004;23:4930-4937.

-43 Lu C, Han HD, Mangala LS, Ali-Fehmi R, Newton CS, Ozbun L, Armaiz-Pena GN, Hu W, Stone RL, Munkarah A, Ravoori MK, Shahzad MM, Lee JW, Mora E, Langley RR, Carroll AR, Matsuo K, Spannuth WA, Schmandt R, Jennings NB, Goodman BW, Jaffe RB, Nick AM, Kim HS, Guven EO, Chen YH, Li LY, Hsu MC, Coleman RL, Calin GA, Denkbas EB, Lim JY, Lee JS, Kundra V, Birrer MJ, Hung MC, Lopez-Berestein G, Sood AK: Regulation of tumor angiogenesis by EZH2. Cancer Cell 2010;18:185-197.

44 Zeidler M, Kleer CG: The Polycomb protein Enhancer of Zeste 2: its link to DNA repair and breast cancer. J Mol Histol 2006;37:219-223.

45 Cao Q, Yu J, Dhanasekaran SM, Kim JH, Mani RS, Tomlins SA, Mehra R, Laxman B, Cao X, Yu J, Kleer CG, Varambally S, Chinnaiyan AM: Repression of E-cadherin by the polycomb group protein EZH2 in cancer. Oncogene 2008;27:7274-7284.

-46 Ougolkov AV, Bilim VN, Billadeau DD: Regulation of pancreatic tumor cell proliferation and chemoresistance by the histone methyltransferase enhancer of zeste homologue 2. Clin Cancer Res 2008;14:6790-6796.

-47 Winter JM, Ting AH, Vilardell F, Gallmeier E, Baylin SB, Hruban RH, Kern SE, Iacobuzio-Donahue CA: Absence of E-cadherin expression distinguishes noncohesive from cohesive pancreatic cancer. Clin Cancer Res 2008; $14: 412-418$. 